\title{
The Impact of Foreign Direct Investment on the Labor Income Share of Listed Companies
}

\author{
Fei Luo \\ College of Economics, Jinan University, Guangzhou, China \\ Email: 15854269912@163.com
}

How to cite this paper: Luo, F. (2020). The Impact of Foreign Direct Investment on the Labor Income Share of Listed Companies. Modern Economy, 11, 541-560. https://doi.org/10.4236/me.2020.112040

Received: January 16, 2020

Accepted: February 22, 2020

Published: February 25, 2020

Copyright $\odot 2020$ by author(s) and Scientific Research Publishing Inc. This work is licensed under the Creative Commons Attribution International License (CC BY 4.0).

http://creativecommons.org/licenses/by/4.0/

\begin{abstract}
Based on the data of China's listed companies in Shanghai Stock Exchange and Shenzhen Stock Exchange from 2003 to 2017, this paper tries to figure out effect of FDI on China's labor income share from a micro perspective. Now the reform and opening up and market-oriented reform in China continue to evolve, but the labor income share of foreign enterprises is not significantly bigger than that of domestic enterprises, which indicates that the promoting effect of foreign direct investment on labor income share of employees of the listed companies in China is declining or disappearing, but high-level control of foreign investors will raise the labor income share.
\end{abstract}

\section{Keywords}

Foreign Direct Investment (FDI), Labor Income Share PSM

\section{Introduction}

Since the reform and opening up policy was implemented in 1978, China has experienced the extraordinary four-decade rapid economic growth, which is known as the "Chinese Miracle". It is difficult for a large-scale economy to maintain a high growth rate for a long period of time, and now China's economic development has entered a stage known as "the new normal of the economy". How to meet the people's growing needs for a better life in the context of economy slowing down and supply side structural reform? How to empower people to equally enjoy the fruits of economic development? These questions have been raised as the big concerns of many scholars and government officials.

As the most populous country on earth China has unparalleled advantage in labor resources, which has attracted a large number of foreign direct investment 
here. The labor-intensive industries developed on the southeast coast in the early days of reform and opening up have created plenty of jobs and much regional economic growth. But in the "Trump era", trade protectionism against globalization is becoming increasingly serious, which has had an impact on China's export; therefore foreign direct investment is now especially important to promote China's economic growth. Just as Xi Jinping (2018) once said that China's open doors would not be closed, they would just get bigger. According to the data of 2016, China still takes the most inflow of foreign direct investment. By relocating factor resources globally, foreign direct investment has profoundly affected the distribution and structure of the home and host countries' "economic factors, especially labor resource". Labor income is the most important source of income for Chinese residents. According to data from the National Bureau of Statistics of China, the proportion of Chinese labor income to GDP dropped from $53.4 \%$ in 1990 to $39.7 \%$ in 2007 , and then increased to $47.5 \%$ in 2017. The decreasing proportion of labor income may cause the income gap to widen further and lead to the decline of consumption, imposing an impact on economic development and social stability. In the recent few years, China has carried out the reform of income distribution, with an emphasis on fairness and equality. According to the 17th National Congress of the CPC report, it is notable policy to lift the proportion of labor income in the primary distribution; In the 18th National Congress of the CPC, it was stressed that the proportion of residents' income should be lifted in national income; in the report of the 19th National Congress of the Communist Party of China, the principle of distribution according to work was emphasized. Around 2008, China's labor income share fell to its lowest level in history and raised a lot of academic discussions. Many scholars have tried to explain this phenomenon from different perspectives, such as technological innovation, the relative price of capital to labor, market demand, changes in economic structure, corporate profitability, tax system, and industrial development (Zhao, 2006; Li, 2007; Jiang \& Wang, 2009; Bai et al., 2008; Bai \& Qian, 2010).

Though China has opened up more and more in terms of many fields after having joined WTO in 2001, At present, few scholars have studied the important topics such as whether foreign direct investment has caused effects on the share of domestic labor income, how it affects labor income share and whether the mechanism or effect have changed over time? Shao Min and Huang Lili (2010) used provincial data from 1998 to 2003 to conduct an empirical test on changes in the labor income share of China's industry sector and concluded that industrial labor income share will decrease as foreign investment increases. Wang Xiongyuan and Huang Yujing (2017) studied the data (2007-2014) of listed companies in Shanghai Stock Exchange and Shenzhen Stock Exchange and concluded that foreign direct investment can increase employees' income share. Over a longer time span, does the change in China's labor income share increase or decrease? Is it necessary to continue to lift the proportion of labor income in national income? What's the effect of foreign direct investment on labor in- 
come? Is it generally positive or negative or is there no effect at all? If the effect of foreign capital inflows is negative, should the foreign investment policy be re-assessed? These questions remain to be answered. Based on the data of China's listed companies in Shanghai Stock Exchange and Shenzhen Stock Exchange from 2003 to 2017, this paper tries to figure out effect of FDI on China's labor income share from a micro perspective. The reform and opening-up and market-oriented reform in China continue to evolve, but now the labor income share of foreign enterprises is not significantly bigger than that of domestic enterprises, which indicates that the promoting effect of foreign direct investment on labor income share of employees of the listed companies in China is disappearing, but high-level control of foreign investors will raise the labor income share.

The potential contribution of this paper may be: Firstly, using micro-data in a long time span to identify the effect of foreign direct investment on Chinese labor income share; secondly, using PSM method to remove the endogenous defects caused by FDI "self-selection effect".

The remainder of the paper proceeds as follows. The next section discusses our theory and hypothesis. The third section describes the research design. Section 4 reports the empirical results and analysis, and the fifth part is the research conclusions and implications.

\section{Theory and Hypothesis}

\subsection{Theoretical Framework}

According to the theoretical frame of neo-classical economics, the share of labor income tends to be constant when economic development stabilizes, which is called as the Kaldor characteristic fact. However, studies about the change of China's labor income share contradicted with Kaldor's characteristic fact. Studies by Luo Changyuan and Zhang Jun (2009), Li Yang and Yin Jianfeng (2009), Bai Chongen and Qian Zhenjie (2010) show that China's labor income share declined between 1993 and 2007. Research by Li Daokui et al. (2009) found that the trend of China's labor income share changed in a U-shape manner. Chang Jinxiong and Wang Danfeng (2011), Wu Shanlin (2011) employed census data and industrial enterprise data from micro-measurements to analyze the trend, concluding that the labor income share of China decreased or changed in a U-shape.

Therefore, a number of literatures began to explore the reasons why China's labor income share declined (Zhao, 2006; Li, 2007; Jiang \& Wang, 2009; Bai et al., 2008; Bai \& Qian, 2010; Luo \& Zhang, 2009; Zhang et al., 2012; Dai \& Cheng, 2014). Some literatures indicate that foreign direct investment is one of the important reasons because enterprises with foreign direct investment are more likely to reduce the demand for low-skilled employees. Compared with high-quality labor group, the bargaining capacity of low-skilled labor group is relatively weak for their supply tends to be unlimited (Feenstra \& Hanson, 1996; Harrison \& McMillan, 2006; Dai \& Cheng, 2014; Zhang et al., 2012). In China, 
the political promotion of local government officials is mainly based on the economic performance of the region and investment is a rather quick and easy way for local government to achieve economic goal. Other researches show that the promotion competition between local government officials in China was highly related to the development of local economy, especially investment promotion (Luo et al., 2015; Wei et al., 2016; Yu \& Yang, 2017). The preferential policies offered by local governments will be at the cost of damaging the interests of workers in order to attract more foreign direct investment (Luo \& Zhang, 2009; Zhang \& Cui, 2019).

Empirical studies in early years have investigated the impact of foreign direct investment on the labor income share. Shao Min and Huang Jiuli (2010) believed that foreign direct investment has a negative "wage spillover" effect on domestic-funded enterprises in that foreign direct investment has widened the wage gap between skilled and unskilled workers. Alexander Hijzen et al. (2015) studied the different motivations of foreign direct investment with labor market. If FDI was market-demand-based, they can be beneficial to the employment of the host country, whereas factor-seeking investment is not obviously beneficial to the employment of the host country.

However, most of the literature on the impact of foreign direct investment on labor income share was at the macro level or from overall empirical analysis. Few studies used micro-level data to obtain more precise impact in different regions of China or different periods. As the positive and negative effects coexisted, the results were not compatible. Generally speaking, only the highly productive companies invested abroad. foreign direct investment brought capital-oriented technological progress, the introduced technology may replace labor force which further reduce the share of labor income. It was likely that foreign companies competed with domestic companies for human resources, raising labor wages to the marginal value of product. In other words, it would increase labor income share (Decreuse \& Maarek, 2011; Xu, 2015; Guo \& Jiang, 2010). But some studies show that the impact of foreign direct investment on labor share from eastern regions to western regions and was not in the same tendency. According to studies of Braconier \& Ekholm (2000), Guo Yuqing \& Jiang Lei (2010), and Chang Ruixue et al. (2019) foreign direct investment flowed in the eastern regions valued the quality of workers and tended to hire employees with high salaries. Under that circumstance, domestic companies have raised the wages, which raised the overall labor share. Tian Wenju \& Wang Ye (2013); Xu Jianwei \& Guo Qiyou (2016) suggested that foreign direct investment in western regions preferred cheap labor and they had the motivation to reduce the labor cost as much as possible, particularly there are preferential policies to attract investment.

Based on the CSMAR Research database from 2003 to 2017, this paper examines how the labor income share is affected by foreign direct investment. Second, it distinguishes the different motivations of foreign investment from three dimensions of region, industry and business. Third, we employ PSM to 
remove the endogenous defects in the study.

\subsection{Research Hypothesis}

With reference to Shao Min and Huang Jiuli (2010), labor income share can be decomposed into

$$
\text { weight }=\frac{w L}{P Q}=\frac{w}{P Q / L}
$$

where $w$ represents the average labor income, $P Q / L$ represents the total labor productivity. The logarithmic form is:

$$
\ln (\text { weight })=\ln (w)-\ln (P Q / L)
$$

In other words, the labor income share is converted into the difference between the average labor income and the total labor productivity. In the study of Dai Xiaoyong and Cheng Liwei (2014), it was proposed that foreign direct investment had a positive wage effect as foreign companies may have a self-selection effect (Helpman et al., 2004). Foreign companies have higher productivity and higher pay ability than domestic companies. Furthermore, they can utilize advanced technologies to raise productivity with rather low cost in the comparison to domestic enterprises. Advanced technologies require highly skilled labor. With more technologies being put into practice, more demand for skilled labor is requested to be satisfied, which could raise the average wage (Guo \& Jiang, 2010). Foreign investment inflows intensify labor market competition, causing strong incentives to raise wages (Decreuse \& Maarek, 2011).

Based on the above analysis, this paper assumed foreign direct investment may cause influence to labor income share in two ways, one of which is through changing average labor income, the other is through changing labor productivity.

$$
\begin{gathered}
\ln (w)_{t}=\alpha * f d i_{t} \\
\ln (P Q / L)_{t}=\beta * f d i_{t} \\
\ln \text { (weight })_{t+1}-\ln (\text { weight })_{t}=(\alpha-\beta) * \Delta f d i
\end{gathered}
$$

That is, the impact of average labor income and total labor productivity on labor income share is converted into the effect of foreign direct investment on labor income share. However, in other literature, it has also been pointed out that foreign direct investment has a negative effect on the labor income share. Some foreign companies in cheap-labor-cost driven industry aim to invest in developing countries to gain access to cheap labor and huge markets, which may decrease the labor income share. When the government attracts foreign investment to introduce competition, preferential policies given to foreign investors are likely to harm the interests of workers (Luo \& Zhang, 2009).

In terms of the effect of foreign direct investment on corporate productivity, most literature point out that foreign direct investment has a positive effect because they bring more advanced management experience, equipment and technologies into host countries (Wang et al., 2015; Zhang et al., 2012; Xing \& Li, 2013). In addition, it is believed that local companies' imitative learning of for- 
eign technology will cause an industrial chain correlation effect and increase their own productivity (Guo \& Jiang, 2010).

Therefore, the effect of foreign direct investment on the labor income share depends on the direction of the wage effect and the dominance of the wage effect and the productivity effect. If the wage effect dominates, the excess profits brought by the increase in productivity are biased towards the labor factor, resulting a positive effect on the labor income share, while when the productivity effect dominates, excess profits brought about by productivity growth are biased toward capital, which decrease the labor income share.

\section{Estimation Methodology}

\subsection{Data and Variables}

In consideration of the availability of data, this article chooses the data of the listed companies in Shanghai stock exchange and Shenzhen stock exchange, from Guotai'an (CSMAR) database as sample. We have also taken the changes of accounting criteria of corporate financial statements in china in 2006 into account,

98,096 initial observations are obtained. and the outliers are processed: 1) exclude those whose average salary is higher than that of senior management; 2 ) exclude ordinary employees whose salary is negative; 3) exclude the companies whose employees are less than 100, according to "draw-type large and small businesses on the principle of division of statistical measures (Interim)" and the following 300 people classified as small businesses; 4) eliminate errors due to the number of employees to measure statistical inconsistencies resulting from employee compensation, exclude workers who rank top 5\% percent and down 5\% in terms of salary (Lu et al., 2012); 5) exclude the labor income share of workers sample greater than the $1 ; 6$ ) exclude samples with controlled variable missing. Finally 3312 observation values were obtained. The data in this paper including the labor income share, corporate governance, corporate characteristics, corporate governance, and foreign control of the employees are from Guotai'an (CSMAR) database. Guotai' an (CSMAR) database is currently the largest scale in China's economic and financial research, with more accurate information and more comprehensive data, of which the series of China's financial and economic database of CSMAR is developed independently by Guotai'an Company and has been protected by national technology patents. So far, more than 1000 well-known universities and financial institutions around the world have recognized this database. What's more, more than 33,000 high-quality academic papers written by more than 15,000 experts and scholars have used this database. Recently, the MSCI China A-share index, pubilshed by Morgan Stanley Barra is also taking a look at Guotai'an (CSMAR) database. Until now, Guotai'an (CSMAR) database has played an important role in the quantitative analysis and empirical research of securities investment in China, which has also been greatly beneficial to our study. 


\subsection{Model Setting and Variable Description}

To test the impact of foreign direct investment on the share of labor income, this empirical model is set as follows in light of the reference to Lu Zhengfei et al. (2012), Jiang Guanhong (2016), Wang Xiongyuan \& Huang Yukun (2017) and Shen Yongjian et al. (2017):

$$
\text { distribution }_{i t}=\alpha_{0}+\alpha_{1} f_{i t}+\beta X_{i t}+\zeta_{i t}
$$

where distribution stands for the labor income share where the proportion of total employee income to total operating income as the proxy variable. This paper chooses two methods to measure the labor income share: 1) cashdtrbt is defined as cash paid to and for employees/gross revenue (All expenses paid to employees for the current period), which derives from Cash Flow Statement, and 2) yfdtrbt is considered by amount to be paid to employees/gross revenue(reflects the company's expenditure on employees whether on or off the job) from Notes to the Statements, and 3) epydtrbt is used to represent the share of ordinary employees. fdi symbols foreign direct investment. To be specific, if there are overseas sponsors in the equity structure of listed companies whether they are founders or overseas circulating shares, fdil will be valued as 1 , otherwise as 0 (Dai \& Cheng, 2014; Janice et al., 2019). Another represent is fdi2 whose calculation is based on the provisions of the Company Law of China that holding more than $25 \%$ of a company's shares is deemed to have a significant impact on the company. If the proportion of foreign direct investment is more than $25 \%$, there is a greater incentive to participate in the governance of the company so that the welfare benefits of workers may be changed and the share of labor income maybe accompany to adjust. Thus, fdi2 is deemed to be 1 if the shares of foreign direct investment in capital structure occupy more than $25 \%$ or it is deemed as 0 .

As for the election of control variables, we refer to the studies of Bai Chongen \& Qian Zhenjie (2010); Luo Changyuan \& Zhang Jun (2009); Lu Zhengfei et al. (2012); Zhang, Lan, \& Pang (2013); Wang Xiongyuan \& Huang Yukun (2017); Shen Yongjian et al. (2017). In order to eliminate the macro-level uncontrollable factors, we control both annual and industry effects. And we further divide China into four regions to study the regional heterogeneity of FDI.

Table 1 presents those control variables and their characteristics as follows.

Due to FDI, we can easily distinguish a company into the experimental group/foreign group and the control group/domestic group. In addition, this paper uses the methods of PSM to precisely identify the impact of foreign direct investment on the labor income share. Rosenbaum and Rubin (1983) proposed the PSM method to achieve dimensionality reduction by incorporating other possible control variables into the logistic regression equation and then to find the closest objects to the experimental group samples according to the propensity score. In order to distinguish between the self-selection effect and the causative effect, we match non-FDI enterprises (control group/domestic group) as much 
Table 1. Control variables and descriptions.

\begin{tabular}{|c|c|c|}
\hline name & symbol & descriptions \\
\hline asset size & size & $\ln$ (total assets) \\
\hline accounting performance & roa & net profit/total assets \\
\hline capital intensity & ci & total assets/operating income \\
\hline capital composition & lev & total liabilities/total assets \\
\hline growth & growth & (total assets $\mathrm{t}_{+1}-$ total assets $\left.\mathrm{t}_{\mathrm{t}}\right) /$ total assets $\mathrm{t}$ \\
\hline age & age & 2017-the year the company was established \\
\hline number of managerial holdings & mngmhldn & $\ln (\Sigma$ managerial holdings $)$ \\
\hline Tobin's q & tobin & $\begin{array}{c}\text { (number of tradable shares }{ }^{*} \text { shares }+ \\
\text { non-tradable or restricted stock }{ }^{*} \\
\text { net assets per share }+ \text { book value } \\
\text { of liabilities)/total assets }\end{array}$ \\
\hline state-owned enterprises dummy & soe & $\begin{array}{c}\text { Value is } 1 \text { if an enterprise is } \\
\text { state-owned enterprises, otherwise is } 0\end{array}$ \\
\hline
\end{tabular}

alike to FDI enterprises (experimental group/foreign group) as possible before regression analysis to quantitatively analyze the net effect of FDI.

\subsection{Descriptive Statistics}

Table 2 shows the division of the sample in the selected year. Panel A exhibits the size and proportion of the foreign group and the domestic group by year. The annual percentage of the foreign group is also much smaller than that of the domestic group, and the largest ratio is only $25 \%$, and the total proportion is only $10 \%$. Among them, the total number of selected samples in 2003 is only 8 companies, but it is basically on the rise year by year. Due to the lack of selection samples, this article excludes the samples from 2012 to 2015. Panel B reflects the annual regional distribution of foreign capital samples. According to the State Council's Regional Division of China, the samples are divided into eastern, central, western and northeast regions. It's obvious that the listed companies in the eastern region have always been far more than other regions, and there have been quite a few foreign companies in Northeast.

Table 3 lists the descriptive statistics of the main variables. The data shows that the standard errors of the three variables used to measure the labor income share are relatively small and the mean is near zero. Enterprises of the two groups are close to each in size. We select less state-owned enterprises that FDI may exert more extensive influence among the market under a relatively weak monopolistic environment. As we can see, the mean age of the sample enterprise is $1.37,3$ years at the maximum, exemplifying the younger trend of the Chinese stock market. 
Table 2. Sample statistics by year. (a) Annual distribution of the sample; (b) Annual regional distribution of foreign sample.

(a)

\begin{tabular}{cccccccccccccc}
\hline year & 2003 & 2004 & 2005 & 2006 & 2007 & 2008 & 2009 & 2010 & 2011 & 2016 & 2017 & total & mean \\
\hline Foreign Group & & & & & & & & & & & & \\
size & 2 & 7 & 11 & 18 & 31 & 29 & 32 & 60 & 67 & 48 & 69 & 374 & 34 \\
proportion & 0.25 & 0.16 & 0.22 & 0.20 & 0.21 & 0.16 & 0.13 & 0.14 & 0.11 & 0.05 & 0.07 & 0.10 & 0.103 \\
Domestic Group & & & & & & & & & & & & & \\
size & 6 & 35 & 39 & 71 & 112 & 151 & 211 & 367 & 504 & 831 & 902 & 3229 & 293.5454 \\
proportion & 0.75 & 0.83 & 0.78 & 0.79 & 0.78 & 0.83 & 0.86 & 0.85 & 0.88 & 0.94 & 0.92 & 0.89 & 0.89 \\
total & 8 & 42 & 50 & 89 & 143 & 180 & 243 & 427 & 571 & 879 & 971 & 3603 & 327.5454 \\
\hline & & & & & & $(\mathrm{b})$ & & & & & & \\
\hline year & 2003 & 2004 & 2005 & 2006 & 2007 & 2008 & 2009 & 2010 & 2011 & 2016 & 2017 & total & mean \\
\hline east & 1 & 4 & 8 & 15 & 25 & 25 & 28 & 52 & 60 & 41 & 55 & 314 & 28.545454 \\
Central & - & - & - & - & 2 & 2 & 2 & 3 & 2 & 2 & 3 & 16 & 2.2857142 \\
west & 1 & 3 & 3 & 3 & 4 & 2 & 2 & 3 & 4 & 5 & 10 & 40 & 3.6363636 \\
northeast & - & - & - & - & - & - & - & 2 & 1 & - & 1 & 4 & 1.3333333 \\
total & 2 & 7 & 11 & 18 & 31 & 29 & 32 & 60 & 67 & 48 & 69 & 374 & 35.800865 \\
\hline
\end{tabular}

Table 3. Descriptive statistics of the main variables of the sample.

\begin{tabular}{ccccc}
\hline variable & mean & sd & $\min$ & $\max$ \\
\hline cashdtrbt & 0.13 & 0.09 & 0.01 & 0.93 \\
yfdtrbt & 0.02 & 0.02 & 0 & 0.08 \\
epydtrbt & 0.02 & 0.01 & -0.01 & 0.07 \\
fdi1 & 0.1 & 0.31 & 0 & 1 \\
fdi2 & 0.05 & 0.22 & 0 & 1 \\
size & 21.4 & 1.05 & 19.2 & 27.46 \\
ci & 2.84 & 3.57 & 0.32 & 95.91 \\
lev & 0.33 & 0.19 & 0.01 & 1.07 \\
growth & 0.26 & 1.57 & -1 & 52.14 \\
soe & 0.2 & 0.4 & 0 & 1 \\
age & 1.37 & 1.28 & 0 & 3 \\
roa & 2170.28 & 1250.83 & 2 & 4359 \\
tobin & 2.83 & 1.98 & 0.05 & 18.05 \\
\hline
\end{tabular}

In the two ways we choose to measure FDI, we can find that the companies with foreign investment are relatively small, the average value is only 0.1 and 0.05 , respectively. The average capital density is small and the difference between samples is large. On the whole, the growth of the company is lower, the average is only 0.26 . And the highest company is nearly 53 times that of the lowest com- 
pany. The accounting performance of the sample as a whole was more average, with an average of around 2170. Tobin's q reflects the value of the company, and the overall mean of the sample is only 2.83 , indicating that the overall recognition of the market value of listed companies in China is low.

Table 4 shows the sample after discriminating between domestic and foreign portfolios. As shown in Table 4, the labor income share is only distinctive in cashdtrbt between domestic and foreign groups while yfdtrbt and epydtrbt is not significant. The likely explanation is that cashdtrbt is compensation for workers actually occurring in the current period as a reflection to the real expenditure. It's hard to perdict or strictly comply with schedule.

Nevertheless, yfdtrbt and epydtrbt indicate the income ought to be paid to employees but possibly not paid or the debt company owes to the employees is not the current period, which can influence the accuracy of outcome variables. except size and ci is significantly different between the two groups, other control variables show no obvious difference.

\section{Empirical Results}

\subsection{Result of Basic Hypothesis}

This section reports our estimation results. Table 5 summarizes the results of

Table 4. Statistics of domestic and foreign listed companies by group and differences test. (a) Basic characteristics of labor income share of employees; (b) Basic characteristics of listed companies.

(a)

\begin{tabular}{cccccc}
\hline \multirow{2}{*}{ Variables } & \multicolumn{2}{c}{ Domestic Group } & \multicolumn{2}{c}{ Foreign Group } & \multicolumn{2}{c}{ Difference test } \\
\cline { 2 - 5 } & $\mathrm{n}$ & Mean1 & $\mathrm{n}$ & Mean2 & Mean Diff \\
\hline cashdtrbt & 3229 & 0.13 & 374 & 0.11 & $0.01^{* * *}$ \\
yfdtrbt & 3229 & 0.02 & 374 & 0.02 & 0.00 \\
epydtrbt & 3229 & 0.02 & 374 & 0.01 & 0.00 \\
\hline
\end{tabular}

(b)

\begin{tabular}{cccccc}
\hline \multirow{2}{*}{ Variables } & \multicolumn{2}{c}{ Domestic Group } & \multicolumn{2}{c}{ Foreign Group } & Difference test \\
\cline { 2 - 5 } & $\mathrm{n}$ & Mean1 & $\mathrm{n}$ & Mean2 & Mean Diff \\
\hline size & 3229 & 21.38 & 374 & 21.59 & $-0.22^{* * *}$ \\
ci & 3222 & 2.88 & 365 & 2.5 & $0.38^{*}$ \\
lev & 3229 & 0.33 & 374 & 0.33 & 0.00 \\
growth & 3216 & 0.24 & 370 & 0.37 & $(0.13)$ \\
soe & 3229 & 0.2 & 374 & 0.24 & $(0.03)$ \\
age & 3229 & 1.38 & 374 & 1.34 & 0.04 \\
roa & 3229 & 2180.69 & 374 & 2077.66 & 103.04 \\
tobin & 3229 & 2.83 & 374 & 2.82 & 0.01 \\
\hline
\end{tabular}

Note: ${ }^{* *},{ }^{* *}$, and ${ }^{\star}$ indicate significant levels of significance at $1 \%, 5 \%$, and $10 \%$, respectively. The following tables are the same. Source: Authors calculated using stata software. 
Table 5. Basic regression results.

\begin{tabular}{|c|c|c|c|c|c|c|}
\hline \multirow{2}{*}{$\square$} & (1) & (2) & (3) & (4) & (5) & (6) \\
\hline & cashdtrbt & cashdtrbt & cashdtrbt & yfdtrbt & yfdtrbt & yfdtrbt \\
\hline \multirow[t]{3}{*}{ fdil } & $-0.014^{\star * \star}$ & $-0.010^{*}$ & $-0.011^{\star \star}$ & & & \\
\hline & $(-3.53)$ & $(-1.85)$ & $(-2.15)$ & & & \\
\hline & & & & -0.000 & $0.004^{\star * \star}$ & $0.003^{* *}$ \\
\hline fdi2 & & & & $(-0.16)$ & $(2.63)$ & (1.98) \\
\hline \multirow[t]{2}{*}{ size } & & $-0.015^{\star * *}$ & $-0.012^{\star * \star}$ & & $-0.002^{* * *}$ & $-0.001^{\star *}$ \\
\hline & & $(-6.43)$ & $(-4.77)$ & & $(-5.51)$ & $(-2.20)$ \\
\hline \multirow[t]{2}{*}{ ci } & & $0.010^{* * *}$ & $0.010^{\star * *}$ & & $0.001^{\star * \star}$ & $0.001^{* * *}$ \\
\hline & & (5.19) & (5.19) & & $(4.75)$ & $(4.65)$ \\
\hline \multirow[t]{2}{*}{ lev } & & 0.012 & $0.020^{*}$ & & $-0.008^{* * *}$ & $-0.005^{\star *}$ \\
\hline & & $(1.03)$ & (1.67) & & $(-4.17)$ & $(-2.35)$ \\
\hline \multirow[t]{2}{*}{ growth } & & 0.002 & 0.002 & & $0.001^{\star * *}$ & $0.001^{\star * *}$ \\
\hline & & $(1.22)$ & (1.07) & & $(3.31)$ & $(3.07)$ \\
\hline \multirow[t]{2}{*}{ soe } & & 0.004 & 0.004 & & $0.002^{\star *}$ & $0.001^{* *}$ \\
\hline & & $(1.05)$ & $(1.00)$ & & $(2.14)$ & $(2.06)$ \\
\hline \multirow[t]{2}{*}{ age } & & $-0.003^{\star *}$ & $-0.002^{\star *}$ & & $-0.000^{* *}$ & $-0.000^{*}$ \\
\hline & & $(-2.25)$ & $(-2.21)$ & & $(-2.01)$ & $(-1.92)$ \\
\hline \multirow[t]{2}{*}{ mngmhldn } & & $-0.002^{\star * \star}$ & $-0.002^{\star * \star}$ & & $-0.000^{\star *}$ & $-0.000^{* * *}$ \\
\hline & & $(-3.29)$ & $(-3.51)$ & & $(-2.55)$ & $(-2.99)$ \\
\hline \multirow[t]{2}{*}{ roa } & & & 0.000 & & & $0.000^{* *}$ \\
\hline & & & (1.10) & & & $(2.07)$ \\
\hline \multirow[t]{2}{*}{ tobin } & & & $0.003^{\star * *}$ & & & $0.001^{\star * *}$ \\
\hline & & & $(3.25)$ & & & (5.98) \\
\hline Time effect & no & yes & yes & no & yes & yes \\
\hline Industry effect & no & yes & yes & no & yes & yes \\
\hline \multirow[t]{2}{*}{ _cons } & $0.128^{\star * *}$ & $0.486^{\star * *}$ & $0.398^{\star * *}$ & $0.020^{\star * *}$ & $0.067^{\star \star \star}$ & $0.037^{\star * *}$ \\
\hline & (76.49) & $(9.35)$ & $(7.26)$ & (77.49) & $(7.75)$ & $(3.85)$ \\
\hline $\mathrm{N}$ & 3605 & 3000 & 3000 & 3605 & 3000 & 3000 \\
\hline
\end{tabular}

$\mathrm{t}$ statistics in parentheses. ${ }^{*} p<0.1,{ }^{* *} p<0.05,{ }^{* * *} p<0.01$.

OLS regression from the entire sample through two methods to measure the labor income share and two methods to measure foreign direct investment. Only FDI variable in the regression can express the direct impact, with no other control variables and fixed effects, and the results are shown in Table 5 (1) and (4). What we can know is that FDI resort a negative effect to labor income share although the coefficient is obvious in column (1), not obvious in column (4). As shown in columns (1), (2) and (3) of Table 5, the OLS estimate of the coefficient of FDI appears significantly negative at the $1 \%$ significance level without the 
control variables and remains notably negative as control variables being added in where the differences between the regression coefficients are not large, which could illustrate that FDI does harm to labor income share.

fdi2 reflects the controlling power of FDI, which we present the results of that power of FDI in Table 4 columns (4), (5) and (6). The greater the power of foreign direct investment, the greater the impact on the labor income share. Although the regression coefficient is small, the coefficient is significantly positive as various control variables are taken into account. It indicates that foreign investors will actively participate in the corporate governance as soon as they can influence the company's major decisions. Form corporate governance aspect, as the results of this article show, when the control power of foreign direct investment increases, it will choose to improve the income situation of employees. It is generally believed that foreign companies have a higher level of corporate governance and participate in the operation and management of listed companies, which will significantly reduce the unnecessary costs to increase company profits, increase company earnings and have a higher probability of increasing employee benefits, etc., which is equivalent to increasing the proportion of labor income in disguise. On the other hand, those companies with the help of more investment are less possible to be constraint to reserve labor cost. On the contrary, there is an incentive to increase employee benefits and increase the proportion of employees' income to draw more high-quality employees. Thus, if FDI does not hold a powerful position in a listed company, they are willing to cut down the labor income share to squeeze costs while they convert their attitude to enhance labor income share once they can make a difference to the companies' goverance, which takes on a U-shape with the weight of FDI rising.

Concerning the influence of control variables, some conclusions are consistent with existing researches that the bigger the company is, the smaller the labor income share; the higher the growth of the company, the more employees will be employed. As the company's profit increases, the level of wages and benefits will be likely improved, thereby increasing the share of labor income. In China, the income of employees in state-owned enterprises is generally higher than that of private enterprises. It's said that the welfare of state-owned enterprises is better and the work is more stable. The remuneration of labor income will grow a little every few years and the share of labor income will increase with more state-owned shares. Roa and Tobin's q is the signals to reflect the performance of a company, whose effect is similar to growth. While labor income share is in the opposition to the age and managerial power. If a company is capital-intensitive, it's reasonable to hire less employees, which ought to reduce labor income share in a normal way. However, in our find, the more capital-intensitive, the larger the labor income share. A convincing reason is that a company is a combination of capital-intensive and technology-intensive where skilled employees take a huge proportion which is possible to sum up the average labor income, though hires less ordinary employees. 


\subsection{PSM Matching Results}

In order to exclude self-selection effect proposed by Dai Xiaoyong and Cheng Liwei (2014), we use Propensity Score Matching method (hereinafter referred to as PSM) to improve the accuracy of model estimation. PSM is a kind of statistical method for the analysis of experimental results using observational data, but due to the irreversibility of time, we can only observe the results before and after the experiment in the experimental group. The result of the experimental group that did not implement cannot be observed (Abadie \& Imbens, 2006). Therefore, one idea is to establish a counter-factual inference model to find a control group which is closest to the experimental group and to compare these matching results for drawing the conclusion. However, thanks to missing variables or multiple collinearity, there may be other variables that interfere with the relationship between independent variables and dependent variables, which makes it difficult to get the net effect of independent variables. Rosenbaum and Rubin (1983) pointed out that PSM can solve the effects of selective errors by incorporating these variables into logist regression equations to ensure the reliability of the results when there are multiple control variables influences and no need to clarify the specific effects of each control variable.

With reference to the previous literature and the control variables selected in this paper, we show the specific matching results in Table 6. Whether it is from the $\mathrm{P}$ value or the $\mathrm{t}$-test mean between experimental group and the control group, it can be seen that there is no obvious difference between the experimental group and the control group, which proves that the control group after PSM matching is close to the condition of the experimental group.

There are three methods consist of caliper matching, nearest neighbor matching and kernel matching to achieve the matching requirements. In this paper, we have employed all three ways and decided to use nearest neighbor matching for robust test as the kernel density function exhibits the best matching result (Figure 1).

Table 7 expresses the result of the labor income share of three types after PSM, indicating that there is no significant difference between domestic and foreign groups.

Table 6. Balanced test results of PSM.

\begin{tabular}{ccccccc}
\hline Mean & \multicolumn{7}{c}{ t-test } \\
\hline Variable & Treated & Control & \%bias & $\mathrm{t}$ & $p>\mathrm{t}$ & $\mathrm{V}(\mathrm{T}) / \mathrm{V}(\mathrm{C})$ \\
\hline size & 21.109 & 21.123 & -1.3 & -0.13 & 0.900 & 1.2 \\
roa & 0.07043 & 0.07011 & 0.5 & 0.05 & 0.961 & 1.17 \\
ci & 3.0315 & 3.0667 & -0.9 & -0.08 & 0.934 & 1.21 \\
lev & 0.38267 & 0.38369 & -0.6 & -0.06 & 0.955 & 0.99 \\
growth & 1.1344 & 1.0473 & 2.1 & 0.21 & 0.830 & $3.14^{*}$ \\
soe & 0.22111 & 0.24749 & -6.6 & -0.62 & 0.536 & \\
mngmhldn & 16.182 & 16.171 & 0.4 & 0.04 & 0.972 & 1.01 \\
\hline
\end{tabular}



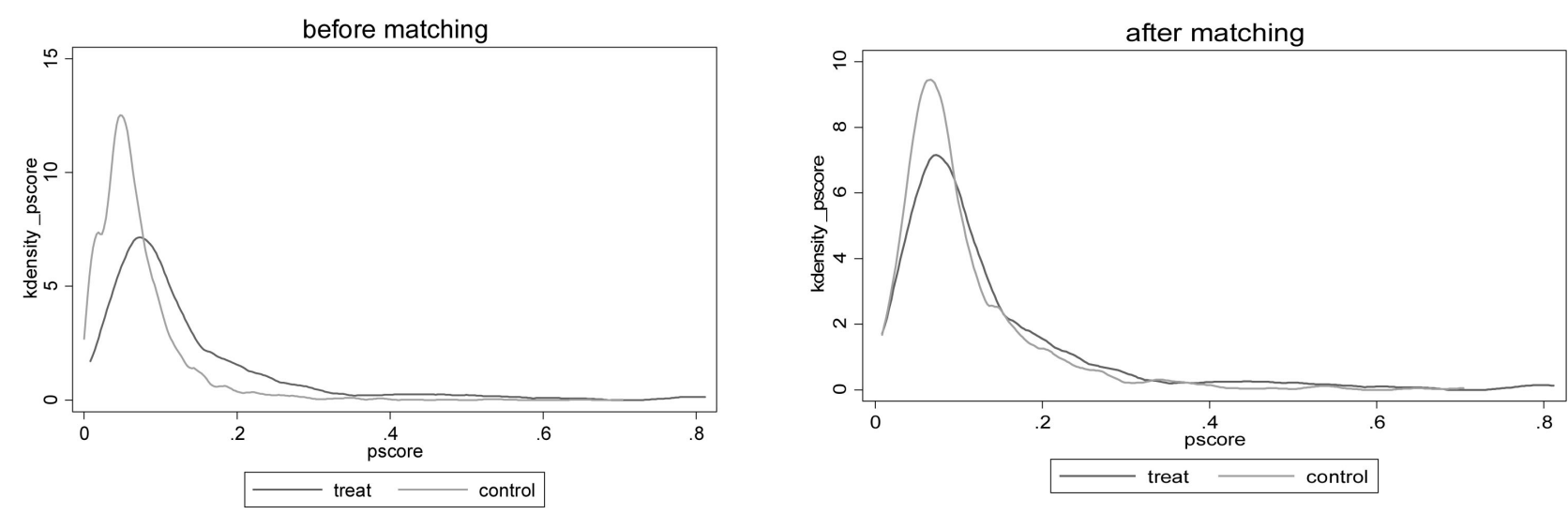

Figure 1. Matching p-score density function graph.

Table 7. PSM results.

\begin{tabular}{ccccccc}
\hline Variable & Sample & Treated & Controls & Difference & S.E. & T-stat \\
\hline cashdtrbt & Unmatched & 0.11621174 & 0.12118329 & -0.00497155 & 0.006180896 & -0.8 \\
& ATT & 0.11666418 & 0.10811889 & 0.008545285 & 0.00728066 & 1.17 \\
& ATU & 0.11500665 & 0.13930466 & 0.024298015 & & \\
yfdtrbt & ATE & & 0.02308673 & & & \\
& Unmatched & 0.02497299 & 0.02516424 & -0.000191245 & 0.0013817 & -0.14 \\
& ATT & 0.02505850 & 0.0230134 & 0.002045022 & 0.001581848 & 1.29 \\
& ATU & 0.02437593 & 0.02671653 & 0.002340601 & & \\
epydtrbt & ATE & & 0.00231787 & & & \\
& Unmatched & 0.01682417 & 0.01532083 & 0.00150334 & 0.001099146 & 1.37 \\
& ATT & 0.01683484 & 0.01595650 & 0.000878336 & 0.001351277 & 0.65 \\
& ATU & 0.01499280 & 0.01635080 & 0.001357999 & & \\
& ATE & & 0.00132111 & & & \\
\hline
\end{tabular}

\section{Robustness of the Results}

To test robustness of the estimated results in the previous section, we conduct additional analyses with the independent variable being replaced by epydtrbt. The labor income share of ordinary employees is expressed as the proportion of the total salary of ordinary employees to the operating income. Fdi1 and fdi2 are still used to measure the impact of foreign direct investment on the labor income share. Based on all observable variables, foreign direct investment has a negative correlation with the labor income share at a significant level of $10 \%$.

On the other hand, we replace the measurement of fdi with the proportion of foreign shares in total share as a robustness test, controlling the industry effect. The results are shown in Table 8, where column (1), (2) and (3) indicate that the effect of foreign direct investment on the labor income share is not advantageous. When the proportion of foreign direct investment is used to measure the role of foreign direct investment, the pure significance of the role of foreign 
Table 8. Robustness test results 1.

\begin{tabular}{|c|c|c|c|c|c|c|}
\hline & (1) & (2) & (3) & (4) & (5) & (6) \\
\hline & epydtrbt & epydtrbt & epydtrbt & epydtrbt & epydtrbt & epydtrbt \\
\hline \multirow[t]{2}{*}{ fdil } & -0.000 & -0.001 & $-0.002^{\star}$ & & & \\
\hline & $(-0.63)$ & $(-1.50)$ & $(-1.93)$ & & & \\
\hline \multirow[t]{2}{*}{ fdi 2} & & & & 0.000 & $0.003^{*}$ & 0.002 \\
\hline & & & & $(0.51)$ & $(1.92)$ & $(1.42)$ \\
\hline \multirow[t]{2}{*}{ size } & & 0.000 & $0.001^{* * *}$ & & 0.000 & $0.001^{* * *}$ \\
\hline & & $(1.32)$ & $(3.30)$ & & $(1.00)$ & $(2.95)$ \\
\hline \multirow[t]{2}{*}{ ci } & & $0.000^{* * *}$ & $0.000^{\star * *}$ & & $0.000^{* * *}$ & $0.000^{* * *}$ \\
\hline & & $(3.87)$ & $(3.83)$ & & $(3.90)$ & $(3.86)$ \\
\hline \multirow[t]{2}{*}{ lev } & & $-0.005^{* * *}$ & -0.003 & & $-0.004^{* * *}$ & -0.002 \\
\hline & & $(-2.90)$ & $(-1.57)$ & & $(-2.79)$ & $(-1.49)$ \\
\hline \multirow[t]{2}{*}{ growth } & & $0.001^{\star * *}$ & $0.001^{* * *}$ & & $0.001^{\star * \star}$ & $0.001^{* * *}$ \\
\hline & & $(3.95)$ & $(3.99)$ & & $(4.08)$ & $(4.11)$ \\
\hline \multirow[t]{2}{*}{ soe } & & 0.001 & 0.001 & & 0.001 & 0.001 \\
\hline & & $(1.15)$ & $(1.08)$ & & $(1.21)$ & $(1.14)$ \\
\hline \multirow[t]{2}{*}{ age } & & $-0.000^{* *}$ & $-0.000^{\star *}$ & & $-0.000^{\star *}$ & $-0.000^{\star *}$ \\
\hline & & $(-2.25)$ & $(-2.19)$ & & $(-2.23)$ & $(-2.16)$ \\
\hline \multirow[t]{2}{*}{ mngmhldn } & & $-0.000^{* * *}$ & $-0.000^{* * *}$ & & $-0.000^{* * *}$ & $-0.000^{* * *}$ \\
\hline & & $(-3.23)$ & $(-3.56)$ & & $(-3.02)$ & $(-3.32)$ \\
\hline \multirow[t]{2}{*}{ roa } & & & $0.000^{*}$ & & & 0.000 \\
\hline & & & $(1.72)$ & & & $(1.61)$ \\
\hline \multirow[t]{2}{*}{ tobin } & & & $0.001^{* * *}$ & & & $0.001^{\star * *}$ \\
\hline & & & $(4.54)$ & & & $(4.41)$ \\
\hline Time effect & no & yes & yes & no & yes & yes \\
\hline Industry effect & no & yes & yes & no & yes & yes \\
\hline \multirow[t]{2}{*}{ _cons } & $0.015^{\star * *}$ & 0.011 & -0.009 & $0.015^{\star * *}$ & 0.010 & -0.010 \\
\hline & $(63.58)$ & $(1.47)$ & $(-1.05)$ & $(65.31)$ & $(1.25)$ & $(-1.14)$ \\
\hline $\mathrm{N}$ & 3605 & 3000 & 3000 & 3605 & 3000 & 3000 \\
\hline
\end{tabular}

direct investment has decreased but is still positive, indicating that under the reform process, the impact of foreign direct investment on the labor income share has no strong promoting effect and China's marketization process is effective.

In terms of qualitative changes, foreign direct investment has not played a role in promoting the labor income share. However, the reflection of foreign direct investment in quantity has shown a positive correlation, indicating that foreign investors have actively participated in corporate governance and improved the welfare of employees. 
Table 9 shows another robustness test with changing roa indicator. There are also significant effects when measuring FDI in two ways. Among them, the regression coefficients of FDI are all negative, along with cashdtrbt at the level of $5 \%$ significance, while fdi 2 that measures foreign control is positively significant at $5 \%$ significance level, which is consistent with previous conclusions, proving the results are robust.

Comparing impact of foreign direct investment to the labor income share in different regions of China is another robustness test we want to conduct. This article divides China's regions into four major sections, namely the eastern region, the western region, the central region and the northeast region. As shown in column (1), (2), (3) and (4) of Table 10, the introduction of foreign direct investment induces a downward tendency to labor income share in all regions, especially at $1 \%$ significance level in western region. From the remaining columns, the coefficients of fdi 2 are all the positive yet insignificant, ensuring the robustness of the conclusion to some degree.

Table 9. Robustness test results 2 .

\begin{tabular}{|c|c|c|c|c|c|c|c|}
\hline & (1) & (2) & (3) & (4) & (5) & (6) & (7) \\
\hline & cashdtrbt & cashdtrbt & yfdtrbt & epydtrbt & cashdtrbt & yfdtrbt & epydtrbt \\
\hline \multirow[t]{2}{*}{ fdil } & $-0.011^{\star *}$ & $-0.011^{\star *}$ & -0.001 & $-0.002^{*}$ & & & \\
\hline & $(-2.11)$ & $(-2.05)$ & $(-0.92)$ & $(-1.85)$ & & & \\
\hline \multirow[t]{2}{*}{ fdi 2} & & & & & 0.010 & $0.003^{\star *}$ & 0.002 \\
\hline & & & & & (1.11) & $(2.12)$ & $(1.53)$ \\
\hline \multirow[t]{2}{*}{ roa2 } & & $-0.163^{\star *}$ & $-0.012^{\star *}$ & $-0.007^{\star *}$ & $-0.164^{\star *}$ & $-0.012^{* *}$ & $-0.007^{\star *}$ \\
\hline & & $(-2.54)$ & $(-2.16)$ & $(-2.02)$ & $(-2.54)$ & $(-2.16)$ & $(-2.04)$ \\
\hline \multirow[t]{2}{*}{ size } & $-0.013^{\star * *}$ & $-0.009^{\star * *}$ & $-0.001^{\star}$ & $0.001^{* * *}$ & $-0.010^{\star \star \star}$ & $-0.001^{\star *}$ & $0.001^{\star * *}$ \\
\hline & $(-5.23)$ & $(-3.41)$ & $(-1.90)$ & (3.43) & $(-3.65)$ & $(-2.21)$ & (3.09) \\
\hline \multirow[t]{2}{*}{$\mathrm{ci}$} & $0.010^{\star * *}$ & $0.009^{\star * *}$ & $0.001^{\star * *}$ & $0.000^{* * *}$ & $0.010^{\star * *}$ & $0.001^{\star * *}$ & $0.000^{* * *}$ \\
\hline & (5.18) & (5.13) & $(4.58)$ & $(3.72)$ & (5.13) & (4.59) & $(3.75)$ \\
\hline \multirow[t]{2}{*}{ lev } & $0.022^{*}$ & 0.000 & $-0.006^{\star * *}$ & $-0.003^{\star}$ & 0.001 & $-0.005^{\star * *}$ & $-0.003^{\star}$ \\
\hline & $(1.84)$ & $(0.02)$ & $(-2.84)$ & $(-1.87)$ & $(0.06)$ & $(-2.80)$ & $(-1.82)$ \\
\hline \multirow[t]{2}{*}{ growth } & 0.002 & 0.003 & $0.001^{* * *}$ & $0.001^{\star * *}$ & 0.002 & $0.001^{\star * *}$ & $0.001^{\star * *}$ \\
\hline & (1.13) & $(1.30)$ & $(3.30)$ & (4.16) & $(1.27)$ & (3.34) & $(4.28)$ \\
\hline \multirow[t]{2}{*}{ soe } & 0.004 & 0.003 & $0.001^{\star}$ & 0.001 & 0.004 & $0.001^{\star *}$ & 0.001 \\
\hline & $(1.01)$ & $(0.84)$ & (1.95) & (1.05) & $(0.90)$ & $(2.01)$ & (1.11) \\
\hline \multirow[t]{2}{*}{ age } & $-0.002^{\star *}$ & $-0.002^{\star \star}$ & $-0.000^{*}$ & $-0.000^{\star *}$ & $-0.002^{\star *}$ & $-0.000^{\star}$ & $-0.000^{* *}$ \\
\hline & $(-2.17)$ & $(-2.09)$ & $(-1.84)$ & $(-2.12)$ & $(-2.06)$ & $(-1.83)$ & $(-2.10)$ \\
\hline \multirow[t]{2}{*}{ mngmhldn } & $-0.002^{\star * \star}$ & $-0.002^{\star \star \star *}$ & $-0.000^{\star * *}$ & $-0.000^{\star * *}$ & $-0.002^{\star * *}$ & $-0.000^{\star * *}$ & $-0.000^{\star * *}$ \\
\hline & $(-3.46)$ & $(-3.22)$ & $(-2.97)$ & $(-3.40)$ & $(-2.98)$ & $(-2.79)$ & $(-3.17)$ \\
\hline \multirow[t]{2}{*}{ tobin } & $0.004^{\star * \star}$ & $0.005^{\star * \star}$ & $0.001^{\star \star \star}$ & $0.001^{\star \star *}$ & $0.005^{\star \star \star}$ & $0.001^{\star * *}$ & $0.001^{\star * \star}$ \\
\hline & $(3.68)$ & $(4.15)$ & $(7.17)$ & $(5.43)$ & $(4.03)$ & $(7.04)$ & $(5.27)$ \\
\hline Time effect & yes & yes & yes & yes & yes & yes & yes \\
\hline Industry effect & yes & yes & yes & yes & yes & yes & yes \\
\hline \multirow[t]{2}{*}{ _cons } & $0.411^{\star * *}$ & $0.343^{\star * *}$ & $0.038^{* * *}$ & -0.009 & $0.338^{\star * *}$ & $0.037^{\star * *}$ & -0.010 \\
\hline & $(7.82)$ & $(5.94)$ & $(4.11)$ & $(-1.03)$ & $(5.87)$ & $(3.97)$ & $(-1.16)$ \\
\hline$N$ & 3000 & 3000 & 3000 & 3000 & 3000 & 3000 & 3000 \\
\hline
\end{tabular}

$t$ statistics in parentheses. ${ }^{\star} p<0.1,{ }^{* *} p<0.05,{ }^{* *} p<0.01$. 
Table 10. Robustness test results 3.

\begin{tabular}{|c|c|c|c|c|c|c|c|c|}
\hline By region & $\begin{array}{l}(1) \\
\text { East }\end{array}$ & $\begin{array}{c}(2) \\
\text { West }\end{array}$ & $\begin{array}{c}\text { (3) } \\
\text { Central }\end{array}$ & $\begin{array}{c}(4) \\
\text { Northeast }\end{array}$ & $\begin{array}{l}\text { (5) } \\
\text { East }\end{array}$ & $\begin{array}{c}(6) \\
\text { West }\end{array}$ & $\begin{array}{c}(7) \\
\text { Central }\end{array}$ & $\begin{array}{c}(8) \\
\text { Northeast }\end{array}$ \\
\hline \multirow[t]{2}{*}{ fdil } & -0.0065 & $-0.0719^{* * *}$ & -0.0229 & -0.0022 & & & & \\
\hline & $(-0.9951)$ & $(-2.6832)$ & $(-0.9589)$ & $(-0.0515)$ & & & & \\
\hline \multirow[t]{2}{*}{ fdi 2} & & & & & 0.0076 & 0.0000 & 0.0247 & 0.0000 \\
\hline & & & & & $(0.7388)$ & (.) & $(0.5874)$ & (.) \\
\hline \multirow[t]{2}{*}{ size } & $-0.0131^{\star * *}$ & $-0.0195^{\star \star}$ & -0.0106 & 0.0061 & $-0.0136^{* * *}$ & $-0.0252^{\star * *}$ & $-0.0124^{*}$ & 0.0060 \\
\hline & $(-5.4101)$ & $(-2.3299)$ & $(-1.4446)$ & $(0.4247)$ & $(-5.5880)$ & $(-3.0758)$ & $(-1.6803)$ & $(0.4266)$ \\
\hline \multirow[t]{2}{*}{ ci } & $0.0119^{* * *}$ & $0.0206^{\star * *}$ & $0.0046^{* * *}$ & $0.0094^{* * *}$ & $0.0119^{\star * *}$ & $0.0191^{* * *}$ & $0.0046^{* * *}$ & $0.0094^{* * *}$ \\
\hline & $(23.9613)$ & (6.9855) & $(5.1389)$ & $(5.2627)$ & (23.9891) & (6.5035) & $(5.1916)$ & $(5.3803)$ \\
\hline \multirow[t]{2}{*}{ lev } & $0.0280^{* *}$ & $0.0739^{*}$ & 0.0327 & $-0.1424^{\star}$ & $0.0284^{* *}$ & $0.0756^{\star}$ & 0.0346 & $-0.1413^{* *}$ \\
\hline & $(2.4775)$ & (1.7984) & $(0.9993)$ & $(-1.9949)$ & $(2.5129)$ & $(1.8135)$ & $(1.0568)$ & $(-2.1123)$ \\
\hline \multirow[t]{2}{*}{ growth } & -0.0003 & -0.0091 & $0.0036^{\star}$ & -0.0075 & -0.0004 & -0.0095 & $0.0037^{\star}$ & -0.0075 \\
\hline & $(-0.1887)$ & $(-1.0880)$ & (1.8902) & $(-0.5184)$ & $(-0.2400)$ & $(-1.1208)$ & $(1.9536)$ & $(-0.5311)$ \\
\hline \multirow[t]{2}{*}{ soe } & 0.0069 & 0.0142 & 0.0040 & -0.0256 & 0.0070 & 0.0122 & 0.0047 & -0.0255 \\
\hline & (1.4430) & $(0.8643)$ & $(0.3191)$ & $(-0.8976)$ & (1.4678) & $(0.7306)$ & $(0.3779)$ & $(-0.9071)$ \\
\hline \multirow[t]{2}{*}{ age } & -0.0014 & $-0.0113^{\star *}$ & $-0.0092^{\star *}$ & $0.0312^{* * *}$ & -0.0014 & $-0.0116^{\star *}$ & $-0.0089^{* *}$ & $0.0313^{* * *}$ \\
\hline & $(-1.0483)$ & $(-2.1861)$ & $(-2.4225)$ & (4.5864) & $(-1.0451)$ & $(-2.1991)$ & $(-2.3202)$ & $(4.7183)$ \\
\hline \multirow[t]{2}{*}{ mngmhldn } & $-0.0020^{* * *}$ & $-0.0045^{\star \star}$ & -0.0036 & $-0.0121^{\star * *}$ & $-0.0018^{* *}$ & $-0.0043^{*}$ & -0.0034 & $-0.0121^{\star * *}$ \\
\hline & $(-2.6249)$ & $(-2.0499)$ & $(-1.6405)$ & $(-2.8157)$ & $(-2.4347)$ & $(-1.9437)$ & $(-1.5429)$ & $(-2.8643)$ \\
\hline \multirow[t]{2}{*}{ roa } & 0.0000 & -0.0000 & 0.0000 & 0.0000 & 0.0000 & -0.0000 & 0.0000 & 0.0000 \\
\hline & $(1.2656)$ & $(-1.2500)$ & $(0.5496)$ & (1.5975) & (1.2194) & $(-1.2691)$ & $(0.3650)$ & $(1.6210)$ \\
\hline \multirow[t]{2}{*}{ tobin } & $0.0029^{* * *}$ & $0.0077^{\star *}$ & 0.0028 & 0.0114 & $0.0028^{* *}$ & $0.0071^{\star *}$ & 0.0027 & 0.0115 \\
\hline & $(2.5845)$ & $(2.3363)$ & $(0.8767)$ & $(1.1035)$ & $(2.4985)$ & $(2.1439)$ & $(0.8514)$ & $(1.1751)$ \\
\hline \multirow[t]{2}{*}{ _cons } & $0.3987^{* * *}$ & $0.6076^{* * *}$ & $0.3404^{\star *}$ & 0.0248 & $0.3949^{* * *}$ & $0.7264^{\star * *}$ & $0.3706^{\star \star}$ & 0.0255 \\
\hline & $(4.1364)$ & $(3.3501)$ & $(2.1760)$ & $(0.0857)$ & $(4.0951)$ & $(4.0686)$ & $(2.3544)$ & $(0.0895)$ \\
\hline adj. R-sq & 0.256 & 0.290 & 0.144 & 0.672 & 0.256 & 0.269 & 0.142 & 0.680 \\
\hline $\mathrm{F}$ & 35.81 & 5.180 & 3.958 & 8.294 & 35.78 & 4.934 & 3.926 & 9.062 \\
\hline $\mathrm{N}$ & 2327 & 226 & 389 & 58 & 2327 & 226 & 389 & 58 \\
\hline
\end{tabular}

t statistics in parentheses. ${ }^{*} p<0.1,{ }^{* *} p<0.05,{ }^{* *} p<0.01$.

\section{Conclusion and Implication}

Based on data from China's listed companies in Shanghai and Shenzhen in 2003-2017, this article examines the impact of foreign direct investment on China's labor income share at the micro level. The results show that foreign direct investment as a whole damages the labor income share of listed companies but the high foreign control will strengthen the promotion of foreign direct investment on the labor income share of employees. However, the listed companies embodied foreign direct investment accounted for only $10.3 \%$ of the total sam- 
ple; a too small proportion may lead to biased regression results. Although we have attempted to match as much similar sample as possible through PSM method and adopted several robustness tests, it can only partially solve the problem of sample bias. On the one hand, due to the serious lack of qualified samples, the sample size of the listed companies in China is small, which may also lead to biased results. On the other hand, the sample companies are young, so the corporate decision-makers have a strong desire to put most of the energy to expand the market share for surviving or developing, which may not be enough to illustrate the impact of the introduction of foreign capital on the share of labor income.

Even so, this article still has implications for China's income distribution reform and labor protection. From the impact of FDI to employee's income share of listed companies, we should be enlightened to notice labor heterogeneity and the different influence of the different amounts of FDI. The inhibiting effect of foreign direct investment on China's labor income share is mainly reflected in the ordinary labor force, and it has a boosting effect on the employees of listed companies. Although the amount of foreign direct investment in China has exceeded the amount of foreign investment in recent years, the role of foreign direct investment has not been as significant as in the early days of reform and opening up, but because of the advanced technology and management experience that foreign direct investment may bring, it can still promote the economic development, and the central government can take the initiative to regulate the level of foreign investment from all kinds of industries to benefit more workers. In addition, at the enterprise level, effective incentives need to be considered to improve the welfare of workers so as to create better performance for enterprises and contribute to the development of the country, such as implementing equity incentive for excellent employees or senior employees, paying employee allowance benefits according to rating regularly, undertaking a more transparent and open employee's reward situation, etc.

\section{Conflicts of Interest}

The author declares no conflicts of interest regarding the publication of this paper.

\section{References}

Abadie, A., \& Imbens, G. (2006). Large Sample Properties of Matching Estimators for Average Treatment Effects. Econometrica, 74, 235-267. https://doi.org/10.1111/j.1468-0262.2006.00655.x

Bai, C. G., \& Qian, Z. J. (2010). Determinants of Labor Income Share: Evidence from Chinese Provincial Panel Data. World Economy, No. 12, 3-27.

Bai, C. G., Qian, Z. J., \&Wu, K. P. (2008). A Study on the Determinants of Factor Allocation in China's Industrial Sector. Economic Research Journal, No. 8, 16-28.

Braconier, H., \& Ekholm, K. (2000). Swedish Multinationals and Competition from Highand Low-Wage Locations. Review of International Economics, 8, 448-461. 
Chang, J. X., \& Wang, D. F. (2011). Labor Share in Initial Allocation: Changing Trends and Factor Contributions. Statistical Studies, 28, 58-64.

Chang, R. X., Chen, Y. S., \& Chen, L. (2019). An Analysis of the Influencing Factors of the Regional Transfer of FDI in China. Market Research, No. 4, 18-19.

Chen, Y. S., \& Chen, L. (2019). An Analysis of the Influencing Factors of the Regional Transfer of FDI in China. Market Research, No. 4, 18-19.

Dai, X. Y., \& Cheng, L. W. (2014). The Impact of Exports and FDI on the Decline of Labor Income Share in China. World Economic Research, No. 8, 74-80 89.

Decreuse, B., \& Maarek, P. (2011). Can the HOS Model Explain the Changes in the Labor Share? - A Tale and Wage Rigidies. Working Paper.

Feenstra, R., \& Hanson, G. (1996). Globalization, Outsourcing and Wage Inequality. American Economic Review, 86, 240-245.

Guo, Y. Q., \& Jiang, L. (2012). Impacts of FDI on Labor Share: Theory and Empirical Research of China. Economic Review, No. 5, 43-51.

Harrison, A. E., \& McMillan, M. S. (2006). Outsourcing Jobs? Multinationals and US Employment. NBER Working Paper 12372. https://doi.org/10.3386/w12372

Helpman, E., Melitz, M. J., \& Yeaple, S. R. (2004). Export Versus FDI with Heterogeneous Firms. American Economic Review, 94, 300-316. https://doi.org/10.1257/000282804322970814

Hijzen, A., Kambayashi, R., Teruyama, H., \& Genda, Y. (2015). The Japanese Labour Market during the Global Financial Crisis and the Role of Non-Standard Work: A Micro Perspective. Journal of The Japanese and International Economies, 38, 260-281. https://doi.org/10.1016/j.jijie.2015.09.003

Janice, S. C., Lei, H. Z., \& Lan, J. L. (2019). The "Employment Effect" of Foreign Direct Investment of Chinese Enterprises: Theoretical Mechanism and Empirical Test. Management Review, 31, 49-59.

Jiang, G. H. (2016). The “Employment Effect” of Chinese Enterprises' Foreign Direct Investment. China Industrial Economy, No. 8, 55-62.

Jiang, L., \& Wang, Z. F. (2009). The Changing Trend and Influencing Factors of the Proportion of Labor Distribution in Modern Departments in China: An Analysis Based on the Data of Provincial Panel of China. Financial and Trade Research, 20, 1-7.

Li, D. K. (2007). Development Strategy, Social Base, Market System-China's Major Economic Issues for the Next 5 to 10 Years. China and World Watch (pp. 32-36, 169-173). China and World Economic Research Center, School of Economics and Management, Tsinghua University.

Li, D. K., Liu, L. L., \& Wang, H. L. (2009). U-Type Law of Labor Share Evolution in GDP. Economic Research Journal, 44, 70-82.

Li, H. B., Guo, J. X., \& Zhai, R. R. (2017). Did Chinese Companies' OFDI Affect Employment Polarization in the Labour Market? Financial Research, 43, 28-39.

Li, Y., \& Yin, J. F. (2009). Exploring High Saving Rates in China: An Analysis Based on the 1992-2003 China Flow of Funds Accounts. Social Sciences in China, 30, 206-228. https://doi.org/10.1080/02529200903342792

Lu, Z. F., Wang, X. Y., \& Zhang, P. (2012). Did State-Owned Companies Pay Higher Wages? Economic Research Journal, 47, 28-39.

Luo, C. Y., \& Zhang, J. (2009). Labor Income Shares (LIS) in Economic Development: An Empirical Study Based on China's Sectoral-Level Data. Social Sciences in China, 30, 
Luo, D. L., She, G. M., \& Chen, J. (2015). Reexamine the Relevance of Economic Growth Performance and Promotion of Local Officials-New Theories and New Evidence Based on Prefecture-Level City Data. Economics (Quarterly), 14, 1145-1172.

Rosenbaum, P., \& Rubin, D. (1983). The Central Role of the Propensity Score in Observational Studies for Causal Effects. Biometrika, 70, 41-55. https://doi.org/10.1093/biomet/70.1.41

Shao, M., \& Huang, J. L. (2010). Foreign Investment and China's Share of Labor Income-An Empirical Study Based on Industrial Industry. Economics (Quarterly), 10, $2-23$.

Shen, Y. J., Yu, S. L., Zhu, D., \& Wu, X. (2017). Labor Cost, Industrial Transfer and Enterprise Value-A Case Study Based on Foxconn Internal Migration Events. Accounting and Economic Research, 31, 56-70.

Tian, W., \& Wang, Y. (2013). An Empirical Study on FDI Inflow and the Contribution of Economic Growth in Western China. China Collective Economy, 31, 21-23.

Wang, X. J., Li, L., \& Liu, P. C. (2015). Foreign Investment Entry, Labor Income Share and Skill Wage Premium-An Empirical Analysis from the Data of the 2008 Service Industry Enterprise Census. Business Economics and Management, No. 2, 78-86.

Wang, X. Y., \& Huang, Y. K. (2017). Foreign Direct Investment and Share of Labor Income of Listed Companies' Employees: Taking Advantage of the Fire or Adding to the Cake. China Industrial Economy, No. 4, 135-164.

Wei, J., Xu, L., \& Ren, B. P. (2016). Fiscal Bias Incentives, Local Government Behavior and Quality of Economic Growth. Economic Science, No. 3, 5-18.

Wu, S. L. (2011). Mechanism of Labor Income Share Determination: A Micro-Model. Economic Research Journal, 46, 55-68.

Xi, J. P. (2018). China's Open Doors Won't Be Closed, They'll Just Get Bigger. http://www.chinanews.com/gn/2018/06-21/8543415.shtml

Xing, C. B., \& Li, C. D. (2013). Technological Progress, Computer Use and the Proportion of Labor Income-Evidence from Data from Chinese Industrial Enterprises. Financial Studies, No. 12, 114-126.

Xu, J. W., \& Guo, Q. Y. (2016). The Interactive Effects of Foreign Direct Investment on Economic Growth, Employment and Wages: An Empirical Study Based on Provincial Panel Data. Economists, No. 6, 15-23.

$\mathrm{Xu}$, S. (2015). The Stage and Regional Characteristics of Foreign Direct Investment-From the Perspective of Labor Income Proportion. World Economic Research, No. 3, 38-46+127-128.

Yu, Y. Z., \& Yang, X. Z. (2017). Officer Tenure, Official Characteristics and Economic Growth Target Setting-Empirical Evidence from 230 Prefecture-Level Cities. Economic Dynamics, No. 2, 51-65.

Zhang, B., Lan, J. P., \& Pang, H. X. (2013). An Empirical Study on the Impact of PE on the Value of Small and Medium-Sized Board and Gem Listed Companies-Based on the Tobin Q value. Macroeconomic research, No. 3, 15-23.

Zhang, J., Bo, M. L., \& Chen, Z. Y. (2012). An Analysis on the Decreasing Causes in the Proportion of Labor Compensation in China's Manufacturing Sector. China Industrial Economics, No. 5, 57-69.

Zhang, W., \& Cui, W. T. (2019). A Study on the Relationship between the Tenure, Promotion Pressure and Economic Growth of Local Officials. Soft Science, 33, 126-130138.

Zhao, J. K. (2006). Proportional Analysis of Labor Distribution in China. Statistical Research, No. 12, 7-12+83. 